\title{
FINANCIAL PERFORMANCE ANALYSIS OF HERO MOTOCORP LTD.
}

\author{
Dr.S. Vijayalakshmi ${ }^{1}$, R. Prarthana Lakshmi ${ }^{2}$ \\ ${ }^{1}$ Head, Department of B.COM PA, PSGR Krishnammal College for Women, Coimbatore, India \\ ${ }^{2}$ III B.COM PA, PSGR Krishnammal College for Women, Coimbatore, India
}

\begin{abstract}
The process of identification of financial strengths and weaknesses of the company by establishing the relationship between the items of balance sheet and profit and loss account is referred to as financial performance analysis. Analyzing financial performance has its importance in internal and external aspects. In this study we have analyzed the financial performance of Hero MotoCorp. Limited (formerly known as Hero Honda) which is an Indian multinational scooter and motorcycle manufacturer by applying trend analysis and profitability ratios. The analysis was performed for a period of five years based on the secondary data obtained from the annual report of the company. It was found that the sales trends, working capital trend and cash flow ratios are fluctuating and suggested the company to improve the ratios by maintaining stability of cash flow and regulate cash flow evenly throughout and try to improve sales to achieve maximum profitability at a minimum cost.
\end{abstract}

Key words: Financial performance, ratio analysis, cash flow analysis, coverage ratios trend analysis, working capital analysis.

\section{INTRODUCTION}

Finance is defined as the management of money and includes activities which include borrowing, investing, budgeting, lending, forecasting and saving. There are three main types of finance: Personal, Corporate and Public / government. Many of the basic concepts in finance originate from micro and macro-economic theory. Financial analysis includes using financial data to evaluate a company's performance and make suggestions about how it can improve going forward. Financial performance analysis comprises of analysis and interpretation of financial statements in such a way that it undertakes full diagnosis of the profitability and financial soundness of the business.

\section{NEED OF THE STUDY}

The aspect of financial performance analysis is a vital one as it reflects the effectiveness of the management. The financial performance of the company is important to measure management as the individuals and groups within the organization that contributes towards the financial objectives of the company.

\section{STATEMENT OF THE PROBLEM}

Finance is treated as the blood of every business organization; business cannot be valued without financial essence. It is mandatory for every company to do a financial performance analysis at the end of each accounting year to know the efficiency and profitability of the company. The financial data helps to analyze the financial performance of the company. Financial performance analysis helps the company to make better decisions regarding the operation of the company.

\section{SCOPE OF THE STUDY}

Financial statement analysis is considered as a part of the whole body of the business analysis. Financial performance analysis of a company may be used by different people for different reasons so the scope of the study varies as per the wants and desires of the persons.

\author{
5. OBJECTIVES OF THE STUDY \\ $\checkmark \quad$ To analyze the cash flow of the company. \\ $\checkmark \quad$ To assess the sales and working capital of the company using trend analysis \\ 6. PERIOD OF THE STUDY \\ The period of study is 5 financial years i.e., from 2015-16 to 2019-20.
}




\section{RESEARCH METHODOLOGY}

Research methodology is a process that is used to identify, select, process and analyze information. It involves studying the methods that are being used in the field of examination. The secondary data of HERO MOTOCORP LIMITED is used for the study.

\section{TOOLS USED}

The tools and methods used in the project are

1.Cash flow analysis:

As they say in finance, cash is king, and, thus, a big emphasis is placed on a company's ability to generate cash flow. Analysts across a wide range of finance careers spend a great deal of time looking at companies' cash flow profiles. 2.Trend analysis

Trend analysis is a technique used in technical analysis that attempts to predict future stock price movements based on recently observed data. It is based on the idea that what has happened in the past gives traders an idea of what will happen in the future.

\section{LIMITATIONS}

$>\quad$ The study is based on secondary data

$>\quad$ Only five years have been taken for the study.

\section{REVIEW OF LITERATURE}

1.Rapheal Nisha (2013) the author tries to evaluate the financial performance of Indian tyre industry. The study was conducted for period 2003-04 to 2011-12 to analyze the performance with financial indicators, sales trend, export trend, production trend etc. The result suggests the key to success in industry is to improve labor productivity and flexibility and capital efficiency.

2.Daniel A. Moses Joshunar (2013) International Journal for Research Trends and Innovation. The study has been conducted to identify the financial strength and weakness of the Tata motors Ltd. using past 5-year financial statements. Trend analysis \& ratio analysis used to comment of financial status of company. Financial performance of company is satisfactory and also suggested to increase the loan levels of company for the better performance.

\section{PROFILE OF THE STUDY}

\section{Overview of the study}

Financial performance analysis is the process of reviewing and analyzing a company's financial statements to make a better economic decision to earn income in the future.

\section{RATIO ANALYSIS}

Financial ratio analysis is a quantitative tool that businesses use to collect valuable insights into a business firm's profitability, solvency, efficiency and liquidity. Ratio analysis provides information to businesses by analyzing the data contained in the firm's income statement, balance sheet and statement of cash flows. Cash flow ratios are applied.

\section{OVERVIEW OF THE COMPANY:}

Hero Honda was initiated in 1984 as a joint venture between Hero Cycles of India and Honda of Japan. In June 2012 , Hero MotoCorp accepted a proposal to merge the investment arm of its parent Hero Investment Pvt. Ltd. with the automaker. This decision was taken 18 months after its split from Hero Honda.

In December 2010, the board of directors of the Hero Honda Group had decided to terminate the joint venture between Hero Group of India and Honda of Japan in a phased manner. The Hero Group would buy out the $26 \%$ stake of the Honda in Joint venture Hero Honda. In July29, 2011 the name of the company was changed from Hero Honda Motors Limited to Hero MotoCorp Limited. British firm Wolff Olin's developed the new brand identity and logo of Hero MotoCorp.

\section{ANALYSIS AND INTERPRETATION}

\section{CURRENT LIABILITY COVERAGE RATIO:}

FORMULA

Net cash from operating activities / Average current liabilities 
International Advanced Research Journal in Science, Engineering and Technology

Impact Factor 7.105 Vol. 9, Issue 1, January 2022

DOI: $10.17148 /$ IARJSET.2022.9159

Table.1. Current liability coverage ratio

\begin{tabular}{|l|l|l|l|}
\hline Year & $\begin{array}{l}\text { Net cash } \\
\text { from } \\
\text { operating } \\
\text { activities }\end{array}$ & $\begin{array}{l}\text { Avg. current } \\
\text { liabilities }\end{array}$ & $\begin{array}{l}\text { Current } \\
\text { liability } \\
\text { coverage } \\
\text { ratio }\end{array}$ \\
\hline $\begin{array}{l}2015- \\
16\end{array}$ & 3913.79 & 3966.12 & 0.987 \\
\hline $\begin{array}{l}2016- \\
17\end{array}$ & 4082.02 & 3770.83 & 1.083 \\
\hline $\begin{array}{l}2017- \\
18\end{array}$ & 3980.86 & 4218.33 & 0.944 \\
\hline $\begin{array}{l}2018- \\
19\end{array}$ & 979.05 & 4236.84 & 0.231 \\
\hline $\begin{array}{l}2019- \\
20\end{array}$ & 5410.10 & 4053.21 & 1.335 \\
\hline
\end{tabular}

\section{current liabilty coverage} ratio

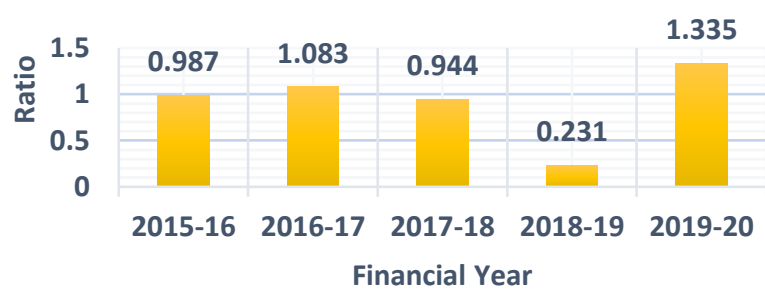

Figure.1. Current liability coverage ratio

\section{Interpretation}

The current liability coverage ratio measures the liquidity of the business. From the above table, current liability coverage ratio is the highest with 1.335 in 2019-20 and least in the financial year 2018-19 with 0. 231. The graph shows that the current liability coverage ratio is fluctuating.

\section{CASH FLOW MARGIN RATIO:}

FORMULA

Cash flow from operating activities/Net sales

Table.2. Cash flow margin ratio

\begin{tabular}{|l|l|l|l|}
\hline Year & $\begin{array}{l}\text { Cash flow } \\
\text { from } \\
\text { operating } \\
\text { activities }\end{array}$ & Net Sales & $\begin{array}{l}\text { Cash flow } \\
\text { margin ratio }\end{array}$ \\
\hline $\begin{array}{l}2015- \\
16\end{array}$ & 3913.79 & $28,599.3$ & $13.7 \%$ \\
\hline $\begin{array}{l}2016- \\
17\end{array}$ & 4082.02 & $30,846.12$ & $13.2 \%$ \\
\hline $\begin{array}{l}2017- \\
18\end{array}$ & 3980.86 & $32,871.82$ & $12.1 \%$ \\
\hline $\begin{array}{l}2018- \\
19\end{array}$ & 979.05 & $33,650.54$ & $2.9 \%$ \\
\hline $\begin{array}{l}2019- \\
20\end{array}$ & 5410.10 & $28,836.09$ & $18.8 \%$ \\
\hline
\end{tabular}


International Advanced Research Journal in Science, Engineering and Technology

Impact Factor $7.105 \div$ Vol. 9, Issue 1, January 2022

DOI: $10.17148 /$ IARJSET.2022.9159

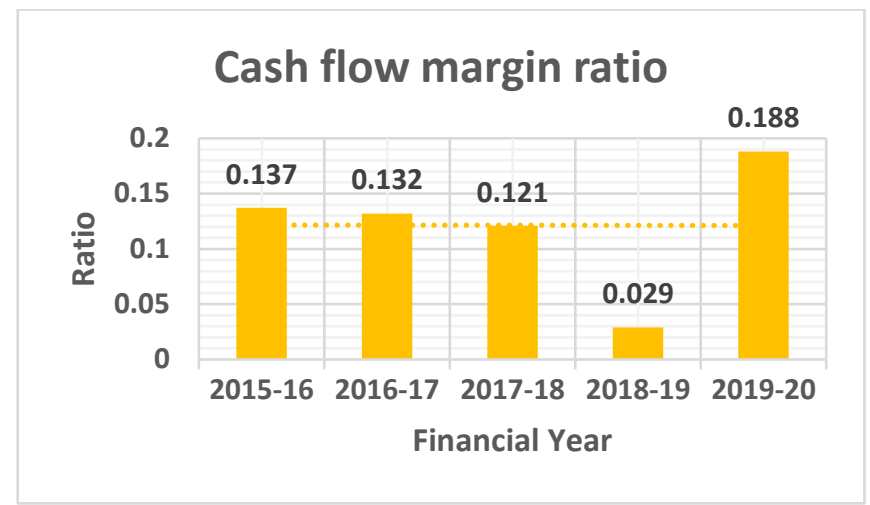

Figure.2. Cash flow margin ratio

\section{Interpretation:}

From the above table the cash flow margin ratio is the highest with 0.188 in the financial year 2019-20 and the least with 0.029 in the financial year 2018-19. The cash flow margin ratio has been fluctuating with huge difference in the financial year 2018-19.

\section{CASH FLOW COVERAGE RATIO:}

\section{FORMULA}

Cash flow from operations/Total debt

Table.3. Cash flow coverage ratio

\begin{tabular}{|l|l|l|l|}
\hline Year & $\begin{array}{l}\text { Cash flow } \\
\text { from } \\
\text { operations }\end{array}$ & Total debt & $\begin{array}{l}\text { Cash flow } \\
\text { coverage } \\
\text { ratio }\end{array}$ \\
\hline $\begin{array}{l}2015- \\
16\end{array}$ & 3913.79 & 4395.94 & 0.89 \\
\hline $\begin{array}{l}2016- \\
17\end{array}$ & 4082.02 & 4582.97 & 0.891 \\
\hline $\begin{array}{l}2017- \\
18\end{array}$ & 3980.86 & 4969.92 & 0.8 \\
\hline $\begin{array}{l}2018- \\
19\end{array}$ & 979.05 & 4784.07 & 0.204 \\
\hline $\begin{array}{l}2019- \\
20\end{array}$ & 5410.10 & 4612.93 & 1.173 \\
\hline
\end{tabular}

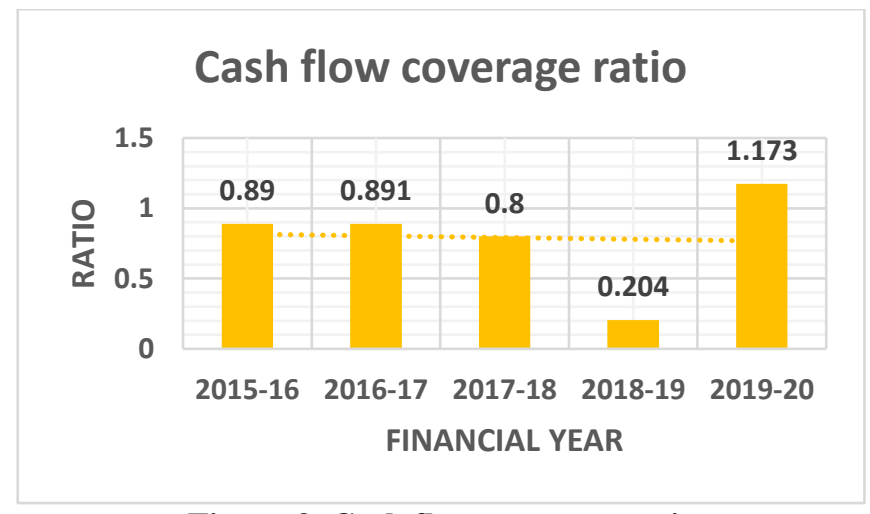

Figure.3. Cash flow coverage ratio

\section{Interpretation}

From the above table cash flow coverage ratio is the highest with 1.173 in the financial year 2019-20 and the least with 0.204 in the financial year 2018-19. The ratio has been nearly constant for the financial years 2015-16 to 201718 and has dropped significantly in the financial year 2018-19. 


\section{TREND ANALYSIS:}

Trend analysis provides a means to analyze company data over a period of time by focusing on the change in specific line items within the income statement and balance sheet. Changes are typically measured in percentages.

\section{SALES TREND ANALYSIS:}

The sales trend analysis has been performed on the financial statement with base year taken as financial year 2015-16.

\section{FORMULA}

(Current year sales/Base year sales) *100

Table.4. Sales trend

\begin{tabular}{|l|l|l|}
\hline Year & Sales (Rs. In crores) & Trend (in \%) \\
\hline $2015-16$ & $30,700.88$ & $100 \%$ \\
\hline $2016-17$ & $30,871.82$ & $100.56 \%$ \\
\hline $2017-18$ & $32,871.82$ & $107.07 \%$ \\
\hline $2018-19$ & $33,650.54$ & $109.61 \%$ \\
\hline $2019-20$ & $28,836.09$ & $93.93 \%$ \\
\hline
\end{tabular}

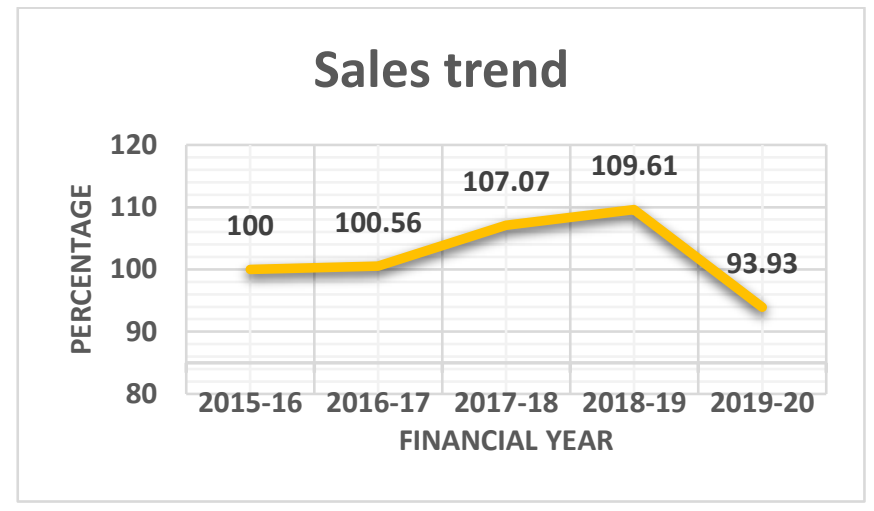

Figure.4. Sales trend

\section{Interpretation:}

The above table shows that the sales has been the highest with 33,650.54 in the financial year 2018-19 and the least with $28,836.09$ in the financial year 2019-20. The trend shows that the sales has been gradually increasing from the financial year 2015-16 to 2018-19 and there is a decrease in trend in the financial year 2019-20.

\section{WORKING CAPITAL TREND ANALYSIS:}

The working capital trend analysis has been performed on the financial statement with base year taken as financial year 2015-16.

FORMULA

(Current year working capital/Base year working capital) $* 100$

Table.5. Working capital trend

\begin{tabular}{|l|l|l|}
\hline Year & $\begin{array}{l}\text { Working capital (Rs. } \\
\text { In crores) }\end{array}$ & Trend (in \%) \\
\hline $2015-16$ & $2,702.90$ & $100 \%$ \\
\hline $2016-17$ & $3,359.85$ & $124.31 \%$ \\
\hline
\end{tabular}


International Advanced Research Journal in Science, Engineering and Technology

Impact Factor $7.105 \div$ Vol. 9, Issue 1, January 2022

DOI: $10.17148 /$ IARJSET.2022.9159

\begin{tabular}{|l|l|l|}
\hline $2017-18$ & $4,504.86$ & $166.67 \%$ \\
\hline $2018-19$ & $3,985.28$ & $147.44 \%$ \\
\hline $2019-20$ & $4,312.50$ & $159.55 \%$ \\
\hline
\end{tabular}

\section{INTERPRETATION:}

The above table shows that the working capital is the highest with 4504.86 in the financial year 2017-18 and the least with 2702.9 in the financial year 2015-16. The trend shows a gradual increase from the financial year 2015-16 to 2017-18 and the trend shows a decrease in 2018-19 and again increased in 2019-20.

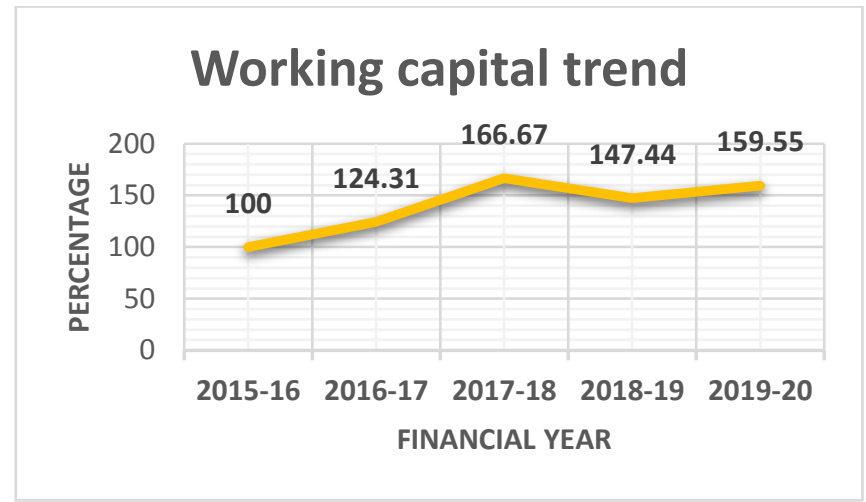

Chart.5. Working capital trend

FINDINGS:

- $\quad$ The net cash balance, current liability coverage ratio, cash flow margin ratio, cash flow coverage ratio is fluctuating in the 5 years.

- The sales trend analysis is fluctuating as it is $100.56 \%$ in $2016-17,107.07 \%$ in $2017-18,109.61 \%$ in $2018-19$, and $93.93 \%$ in $2019-20$.

- The working capital trend analysis is fluctuating as it is $124.31 \%$ in $2016-17,166.67 \%$ in $2017-18,147.44 \%$ in 2018-19, and $159.55 \%$ in $2019-20$.

\section{SUGGESTIONS:}

The net cash balance, current liability coverage ratio, cash flow margin ratio, cash flow coverage ratio is fluctuating in the years covered under the period of study. suggested the company to improve the ratios by maintaining stability of cash flow and regulate cash flow evenly throughout and try to improve sales to achieve maximum profitability at a minimum cost.

\section{CONCLUSION:}

The purpose of financial performance analysis is to identify the financial strengths and weaknesses of the firm by properly establishing the relationship between the items of balance sheet and profit and loss account. This helps in planning the financial performance of the company in the future. From the analysis, it is concluded that Hero MotoCorp limited can try to follow the suggestions presented above to improve its profit and increase turnover in the upcoming years. If they can properly implement the above suggested techniques, they can maximize profits with minimum costs.

\section{REFERENCES:}

\section{Journals:}

> R.Idhayajyothi,Dr.O.T.V.Latasri, N.Manjula, A.Meharaj Banu, and R.Malini(2014)-A study on financial performance of Ashok Leyland Limited at Chennai. e-ISSN:2278-487X, p-ISSN: 23197668.Volume 16, Issue 6. Ver.1(June 2014) 
International Advanced Research Journal in Science, Engineering and Technology

Impact Factor $7.105 \div$ Vol. 9, Issue 1, January 2022

DOI: 10.17148/IARJSET.2022.9159

Pratik.P.Valand-An Empirical study of Ratio Analysis Indian Journal of Applied research,Volume:I,Issue:2,October 2012.

Book:

C. Padmaprabha (2007) - Accounting for Management, vol.1, pp.18.1-18.16

Websites:

> https://en.wikipedia.org/wiki/Hero_MotoCorp

$>\quad$ https://cleartax.in/g/terms/ratio-analysis

$>\quad$ https://www.heromotocorp.com/en-in/investors/annual-reports.html

$>\quad$ https://www.accountingtools.com/articles/ratio-analysis.html

$>\quad$ https://www.simplilearn.com/financial-performance-rar21-article

$>\quad$ https://efinancemanagement.com/financial-analysis/efficiency-ratios

$>\quad$ https://corporatefinanceinstitute.com/resources/knowledge/finance/solvency-ratio/ 